\title{
Hookworm Disease in Immigrants
}

\author{
S. N. SALEM,* M.B., CH.B., M.R.C.P.ED., D.T.M.\&H ; S. C. TRUELOVE,* M.D., F.R.C.P.
}

Brit. med. F., 1964, 1, 1074-1077

Hookworm disease is an important cause of ill-health in many tropical and subtropical countries, especially when conditions are insanitary. It may also occur in mining communities in Europe if there is a combination of hot moist conditions and poor hygiene (Adams and Maegraith, 1960).

The disease causes iron-deficiency anaemia because of loss of blood. The worm attaches itself to the mucosa of the small intestine and sucks the blood of the human host, passing it through its own lumen into the lumen of the gut. In addition, there is oozing of blood from the sites of attachment of the worm. The average loss of blood is about $0.3 \mathrm{ml}$. per worm per day. It is obvious that if the infestation is heavy, with hundreds of worms present, the loss of blood is considerable (Foy and Kondi, 1960, 1961). There may also be gastrointestinal symptoms, which sometimes occur even when there is no anaemia. Symptoms resembling those of chronic peptic ulcer are comparatively common.

Until quite recently, hookworm disease was a rarity in Great Britain. For example, in a review of 5,000 cases of anaemia, French and Israëls (1955) had no examples of this condition. The recent flood of immigrants into Great Britain from tropical countries of the Commonwealth means that hookworm disease must enter into the differential diagnosis when a patient presents with anaemia or gastro-intestinal symptoms.

We illustrate this contention by describing four cases recently seen by us; in one the presentation was unusual and took the form of haematemesis and melaena, while the others suffered from the usual type of chronic iron-deficiency anaemia.

\section{Case 1}

An unmarried male Pakistani aged 23, a confectioner by occupation and resident in this country for 16 months, was referred to us because of the rapid onset of dizziness, double vision, and tiredness after an episode of vomiting blood and passing dark stools a week before. His blood had been examined by his general practitioner and was found to show severe anaemia, the haemoglobin value being $5.4 \mathrm{~g} . / 100 \mathrm{ml}$.

On 13 July 1963 he was seen by us in the out-patient clinic. He was pale but well built and alert.

Examination.-Conjunctivae pale. Tongue and mouth normal. No palpable lymph nodes. Finger-nails normal. No breathlessness and no ankle oedema. Cardiovascular system: pulse $90 / \mathrm{min}$., regular ; B.P. 120/60 ; soft mid-systolic murmur but heart sounds otherwise normal. Lungs clear. Abdomen normal ; liver and spleen impalpable ; no tender areas. Rectal examination normal. Central nervous system normal. Fundi normal. Blood: haemoglobin 5.4 g. $/ 100 \mathrm{ml}$; P.C.V. $25 \%$; film: marked hypochromia, increased number of polychromatic cells, and tendency to macrocytosis suggestive of multiple deficiency anaemia ; $24 \%$ of the white cells were eosinophils.

Likely possibilities appeared to be a bleeding peptic ulcer and hookworm infestation. He was admitted on 16 July and the following tests were done:

Investigations.-Blood: haemoglobin 8.1 g./100 ml.; R.B.C. $3,730,000 /$ c.mm. ; C.I. 0.85 ; reticulocytes $12 \%$; M.C.H.C. $27 \%$; P.C.V. $30 \%$; W.B.C. $8,200 /$ c.mm (eosinophils $10 \%$, neutrophils $55 \%$, monocytes $14 \%$, lymphocytes $19 \%$ ); E.S.R. $3 \mathrm{~mm} . / \mathrm{hr}$.

* Nuffield Department of Clinical Medicine, University of Oxford. From the Radcliffe Infirmary, Oxford.
(Westergren) ; platelets normal ; serum iron $20 \mu \mathrm{g} . / 100 \mathrm{ml}$. ; serum vitamin $\mathrm{B}_{12} 340 \mu \mu \mathrm{g} . / \mathrm{ml}$; serum folic acid $2.7 \mu \mathrm{g} . / \mathrm{ml}$.; sternal marrow iron deficient ; blood group $\mathrm{A}, \mathrm{Rh}$ negative ; prothrombin time (Owren's method) $59 \%$ of normal, then $61 \%$, then $86 \%$ with vitamin $\mathrm{K} 10 \mathrm{mg}$. intramuscularly each day for three days. Liverfunction tests: flocculation tests negative ; B.S.P. $8 \%$ retained after 45 minutes; bilirubin $0.2 \mathrm{mg} . / 100 \mathrm{ml}$; alkaline phosphatase 4 units ; total proteins $6 \mathrm{mg}$., albumin $3.8 \mathrm{~g}$. ; plasma electrophoresis normal ; S.G.P.T. 16 units; blood urea $25 \mathrm{mg} . / 100 \mathrm{ml}$. Stools: occult blood strongly positive over three days; large numbers of hookworm ova were found in a smear; the estimated worm-load by total egg-count for three days was about 800 worms $(21,000$

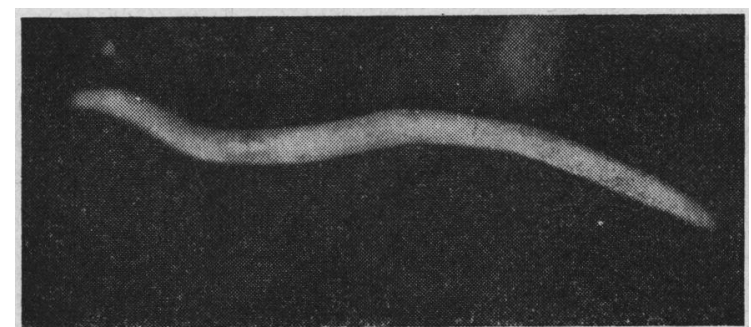

FIG. 1.-Photograph of the hookworm brought up by the Crosby capsule from the small intestine in Case 1 .

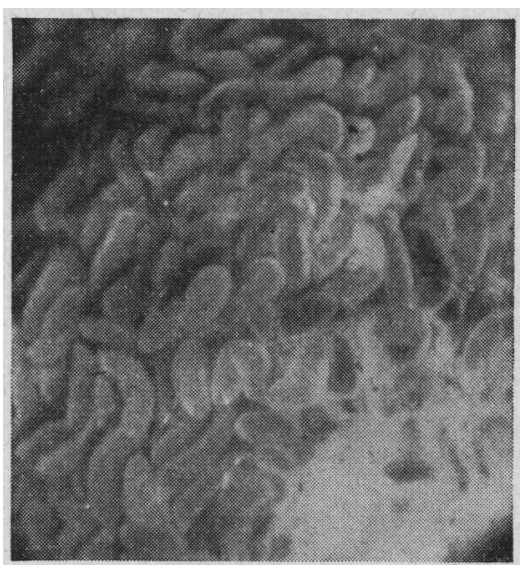

FIG. 2.-Dissecting-microscope appearances of the jejunal biopsy specimen in Case 1. Leaf-shaped villi and ridges are seen.

ova/g. faeces) ; faecal fat $2.7 \mathrm{~g} . / 24$ hours, vitamin $\mathbf{B}_{12}$ absorption normal ; no Rh or immune antibodies detected. Electrolytes normal. Urine normal. Gastric biopsy normal. Barium meal and followthrough: oesophagus, stomach, and duodenum-no abnormalities ; upper intestine-considerable irregularities of the small-bowel pattern.

Fejunal Biopsy.-A Crosby capsule was used, and this brought out with the jejunal biopsy specimen a live hookworm which measured $12 \mathrm{~mm}$. in length and which survived for 8 hours 15 minutes in a closed bottle containing normal saline. Vigorous movement of the worm was obtained by exposing it to strong artificial light. Fig. 1 is a photograph of the worm after death. Under dissecting microscope the biopsy specimen showed an excess of tongue-shaped and leaf-shaped villi, excess of ridges, and a partially convoluted mucosa (Fig. 2). Histological report (Dr. W. C. D. Richards): Abnormal villous pattern. The villi had an irregular shape and in a few places the gland layer was increased in thickness. In the submucosa and muscular layer there were foci of 
infiltration with eosinophils which were related to the small mucosal erosions (Fig. 3).

On 27 July the patient was given $15 \mathrm{~g}$. of bephenium hydroxynaphthoate ("alcopar") because of the heavy load of worms, and $30 \mathrm{~g}$. of magnesium sulphate 2 hours later. He had been taking ferrous sulphate, 5 gr. ( 320 mg.) t.d.s., since admission, and he continued on this dose for four weeks after his discharge. He was discharged on 28 July with a haemoglobin $9.5 \mathrm{~g} . / 100 \mathrm{ml}$. and $15 \%$ reticulocytes. He had gained about a stone $(6.4 \mathrm{~kg}$.) in weight and was symptom-free. Four weeks later the haemoglobin had risen to $15.4 \mathrm{~g} . / 100 \mathrm{ml}$. (see Fig. 4).

A second jejunal biopsy (two months after treatment with bephenium hydroxynaphthoate) showed a few leaf-shaped villi, but otherwise the appearances were entirely normal.

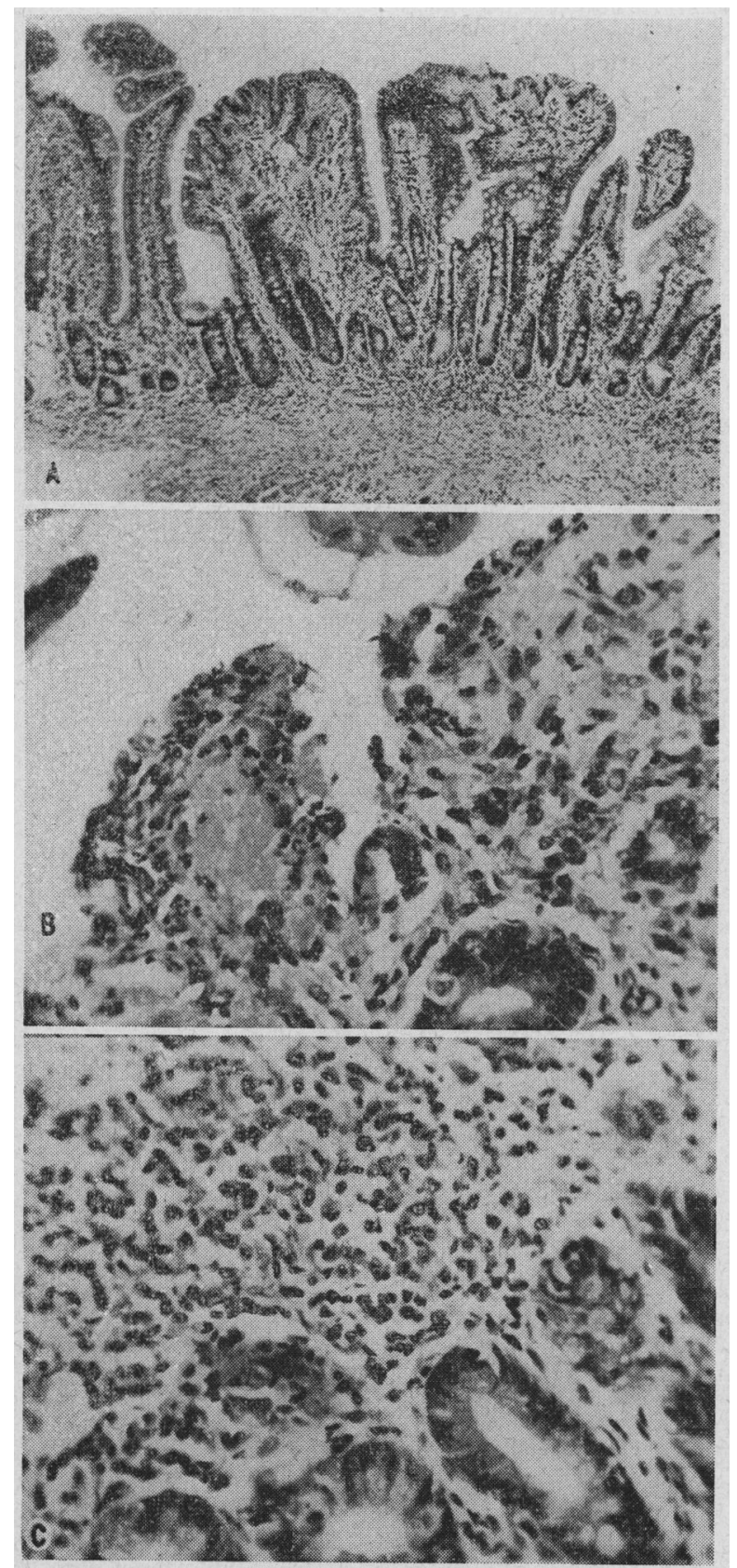

FIG. 3.- Histological appearances of the jeiunal biopsy specimen in Case 1. A, Low-power view showing abnormal villi. B, high-power view of a surface erosion. C, High-power view of inflammatory cell infiltration of the lamina propria.

\section{Case 2}

A male Pakistani aged 25, resident in Great Britain for 18 months and working as a labourer in a dairy firm, complained of poor colour for 12 months in spite of taking iron pills for most of the time; there were no gastro-intestinal symptoms. His haemoglobin value as an out-patient was found to be $10.6 \mathrm{~g} . / 100 \mathrm{ml}$. and the blood smear showed the appearance of iron-deficiency anaemia. His appetite was vigorous and his weight steady. He smoked 10 cigarettes a day and did not drink. He was married and had three children who were living in Pakistan.

He was admitted on 16 September 1963 for investigation.

Examination.-Alert and intelligent. Tongue and nails normal. Cardiovascular system: pulse $66 / \mathrm{min}$.; B.P. $115 / 60$. Lungs clear. Abdomen: spleen and liver impalpable ; no glands or masses felt ; no tender areas. Rectal examination normal. Central nervous system normal.

Investigations.-Blood: haemoglobin 10.6 g./100 ml.; R.B.C. $4,800,000 /$ c.mm. ; C.I. 0.75 ; reticulocytes $4.2 \%$; M.C.H.C. $27 \%$; P.C.V. $39 \%$; W.B.C. $10,000 /$ c.mm. (eosinophils $14 \%$, neutrophils $69 \%$, lymphocytes $15 \%$ ); E.S.R. $3 \mathrm{~mm} . / \mathrm{hr}$. (Westergren); W.R. and $\mathrm{Kahn}$ negative. Liver-function tests: flocculation tests negative; bilirubin $0.2 \mathrm{mg} . / 100 \mathrm{ml}$.; alkaline phosphatase 9 units; total proteins $6.3 \mathrm{~g}$., albumin $3 \mathrm{~g}$. ; blood urea $25 \mathrm{mg} . / 100 \mathrm{ml}$. Stools : occult blood strongly positive; faecal smear showed many hookworm ova. Urine normal. Chest $x$-ray picture normal. Barium meal and follow-through: oesophagus and stomach normal; duodenum normal ; upper part of jejunum slightly dilated, with thickening of the mucosal folds and cogwheel irregularities.

Examination of the jejunal biopsy specimen under a dissecting microscope showed an increased number of leaf-shaped villi as well as numbers of curled and convoluted ridges. Histology: no evidence of ulceration or of erosion was seen in the sections. The epithelium was essentially normal. Long mucosal ridges of $1,000 \mu$ were found. No abnormality was seen in the intestinal glands. The lamina propria showed vascular congestion and slightly increased cellular infiltration. The inflammatory cells included plasma cells and some eosinophil leucocytes (Dr. W. C. D. Ricinards).

The patient was given $10 \mathrm{~g}$. of bephenium hydroxynaphthoate followed by $2 \mathrm{oz}$. of magnesium sulphate, and was discharged home with haemoglobin $10.4 \mathrm{~g} . / 100 \mathrm{ml}$. to continue on ferrous gluconate $300 \mathrm{mg}$. t.d.s. and to attend the anaemia clinic three weeks later for follow-up. By that time the haemoglobin was normal (14.5 g./ $100 \mathrm{ml}$.) (see Fig. 4).

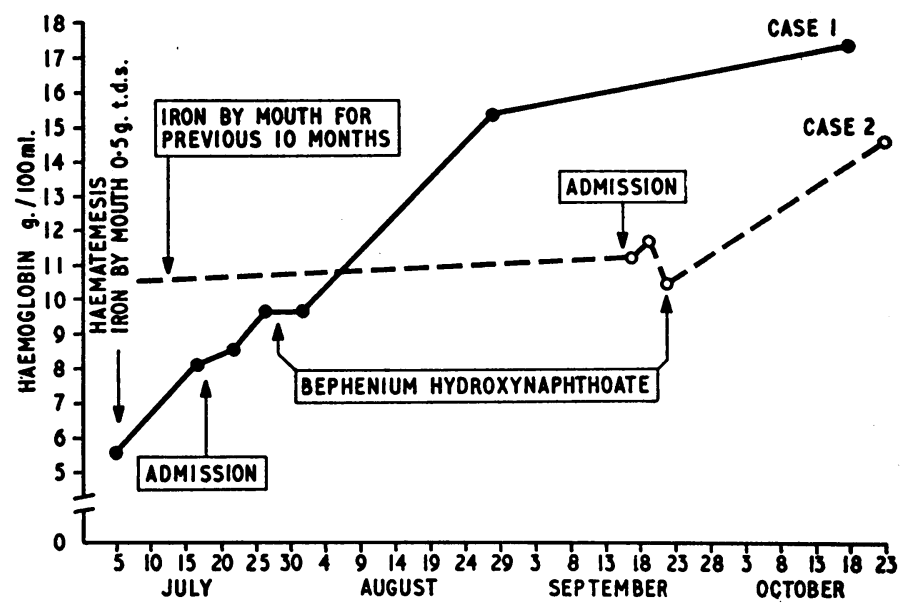

Fig. 4. - Serial changes in the haemoglobin value in Cases 1 and 2 in relation to treatment with bephenium hydroxynaphthoate.

\section{Case 3}

A married male Pakistani aged 37, resident in Oxford and working as a builder's labourer, was admitted on 12 February 1964 as an emergency under the care of Dr. P. C. Mallam after collapsing at work. For the past two months he had noticed increasing fatigue, pain in the legs on exertion, pain in the chest on exertion, and cough. A few days before admission he passed a blackish stool.

Examination.-Clinically anaemic. The cardiovascular system showed atrial fibrillation, but the heart sounds were normal and there was no evidence of congestive heart failure; the pulse rate and blood-pressure were normal. Other systems normal.

Investigations.-Blood: haemoglobin 5.6 g. $/ 100 \mathrm{ml}$; P.C.V. $23 \%$; M.C.H.C. $24 \%$; film showed marked hypochromia, anisocytosis, microcytosis and poikilocytosis ; W.B.C. 5,000/c.mm., with 
$12 \%$ eosinophils. Stools : occult blood positive; moderate numbers of hookworm ova present; faecal fat 17.6 g./24 hours. Xylose test borderline. $X$-ray chest: no gross abnormality. Barium meal and follow-through: normal. Barium enema normal.

fejunal Biopsy.-Dissecting microscope revealed many large leafshaped villi and a number of convoluted villous ridges. Histology: irregular villi, with some branching, and infiltration of the lamina propria with interstitial cells, many of which were eosinophils. No ulceration.

Gastric Biopsy.-Normal.

$\mathrm{He}$ was treated with bephenium hydroxynaphthoate and oral iron, and on discharge the haemoglobin value had risen to $9.9 \mathrm{~g} . /$ $100 \mathrm{ml}$. Re-examination of the stools showed no hookworm ova.

\section{Case 4}

An unmarried Pakistani aged 20, resident in Oxford and variously employed, came to us with a history of generalized weakness and tiredness for several months. He was pale and underweight, but there were no localizing signs.

Investigations.-Blood: haemoglobin $10.4 \mathrm{~g} . / 100 \mathrm{ml}$; film showed hypochromia ; W.B.C. $6,400 /$ c.mm. with $8 \%$ eosinophils. Stools: moderate number of hookworm ova; faecal fat $8.4 \mathrm{~g} . /$ 24 hours.

fejunal Biopsy.-Dissecting microscope showed numerous leafshaped villi and a few elongated villous ridges. Histology: mild irregularity of villi but no other abnormality.

He was treated with bephenium hydroxynaphthoate and oral iron. Eight weeks later the haemoglobin value was $16.1 \mathrm{~g} . / 100 \mathrm{ml}$. and the blood film was normal. Re-examination of the stools showed no hookworm ova.

\section{Discussion}

The effects of hookworm disease depend upon a number of factors, such as the heaviness of the infestation, the type of worm, and the nutritional standards of the patient. With a heavy load of worms, the loss of blood is considerable. Ancylostoma duodenale is more damaging than Necator americanus. If the diet is inadequate and contains little firstclass protein the effects are potentiated (W.H.O., 1959). Other factors which may render the disease overt are physical stress, intercurrent infection, and pregnancy (Blacklock and Southwell, 1961).

Immigrants from tropical countries are often infested with hookworms. They frequently work hard and live poorly in this country in order to save money to support their families in their native land, so that their nutrition often falls below minimum desirable standards, especially as regards highquality protein. Anaemia is therefore likely to occur in such persons. Treatment with iron is inadequate (Foy and Kondi, 1961), and this is illustrated by our second patient, who had been on treatment with ferrous sulphate for a year without success, but who responded promptly as soon as a specific anthelmintic was employed.

Although iron-deficiency anaemia is the most common effect of hookworm disease, other effects may occur. Recently it has been found that the malabsorption syndrome with steatorrhoea may occur, possibly as a direct result of widespread smallintestinal mucosal damage, as biopsy specimens have shown definite abnormalities (Sheehy et al., 1962). In three of our patients the small-intestinal mucosae were abnormal as judged by biopsy specimens. One had a definite steatorrhoea while another had a faecal-fat excretion which was somewhat above the normal limit.

Gastro-intestinal symptoms are common and often resemble those of peptic ulcer. One of our patients presented with haematemesis and melaena, followed by the symptoms of severe anaemia. A peptic ulcer was suspected as a possibility, but investigation did not support this, and the heavy bleeding was probably related to a low prothrombin level and the mucosal erosions. The worms produce an anticoagulant which prevents the host's blood from clotting at the site of attachment of the worm, but whether the low prothrombin value was related to this fact is unknown.

Hookworm infestation may be much more common among our immigrant population than is generally suspected. Examination of the stools of nine other Pakistanis not under medical care has shown hookworm ova to be present in five, of whom three gave positive tests for occult blood. One of these nine subjects is thin and weak, and complains of symptoms suggestive of anaemia, but is not willing to be fully investigated and treated because he cannot afford to stop working. Miller and Bamforth (1962) routinely examined 99 apparently healthy coloured immigrants and found hookworm ova in the stools of 13 of them, although only two of the subjects were anaemic. The same authors also analysed the case-records of 34 patients with hookworm disease treated in St. Thomas's Hospital during the previous five years and found that 28 of the cases were seen in the latter part of the quinquennium under review. Similarly, in our own hospital, the patients diagnosed as suffering from hookworm disease have increased sharply in number during the past year (see Table).

\begin{tabular}{|c|c|c|c|c|c|}
\hline Sex & $\begin{array}{l}\text { Age in } \\
\text { Years }\end{array}$ & $\begin{array}{l}\text { Nation- } \\
\text { ality }\end{array}$ & $\begin{array}{l}\text { Presenting } \\
\text { Symptoms } \\
\end{array}$ & $\begin{array}{c}\text { Year of } \\
\text { Diagnosis }\end{array}$ & Remarks \\
\hline $\mathbf{F}$ & $1 t$ & English & Cleft palate, & 1958 & Born in \\
\hline $\begin{array}{l}\mathbf{M} \\
\mathbf{M} \\
\mathbf{M}\end{array}$ & $\begin{array}{l}29 \\
36 \\
25\end{array}$ & $\begin{array}{l}\text { W. Indian } \\
\text { Pakistani } \\
\text { Nigerian }\end{array}$ & $\begin{array}{l}\text { Anaemia } \\
\text { Poliomyelitis, }\end{array}$ & $\begin{array}{l}1959 \\
1959 \\
1960\end{array}$ & \\
\hline $\begin{array}{l}M \\
M \\
M \\
M\end{array}$ & $\begin{array}{l}32 \\
19 \\
36 \\
25\end{array}$ & $\begin{array}{l}\text { W. Indian } \\
\text { "̈akistani } \\
\text { English }\end{array}$ & $\begin{array}{l}\text { Anaemia, ? yaws } \\
\text { Anaemia, melaena } \\
\text { Anaemia, collapse } \\
\text { Anaemia }\end{array}$ & $\begin{array}{l}1962 \\
1963 \\
1963 \\
1963\end{array}$ & 3 years in \\
\hline $\begin{array}{l}M \\
M \\
M\end{array}$ & $\begin{array}{l}35 \\
42 \\
23\end{array}$ & $\begin{array}{c}\text { Pakistani } \\
\text {," }\end{array}$ & $\begin{array}{l}\text { Diärhoea, anaemia } \\
\text { Haematemesis, } \\
\text { melaena }\end{array}$ & $\begin{array}{l}1963 \\
1963 \\
1963\end{array}$ & Case 1 \\
\hline $\begin{array}{l}\mathbf{M} \\
\mathbf{M} \\
\mathbf{M}\end{array}$ & $\begin{array}{l}25 \\
37 \\
20\end{array}$ & ", & $\begin{array}{l}\text { melaena } \\
\text { Anaemia } \\
\text { Generalized } \\
\text { weakness }\end{array}$ & $\begin{array}{l}1963 \\
1964 \\
1964\end{array}$ & $\begin{array}{ll}\Rightarrow & 2 \\
" & 3 \\
" & 4\end{array}$ \\
\hline
\end{tabular}

These findings suggest that a problem of public health exists on two distinct counts. First, there are possibly many immigrants who require treatment for their own health. Secondly, it is conceivable that under the cramped and insanitary conditions in which many of these subjects live, hookworm disease could spread in Great Britain and not remain confined to its original hosts.

\section{Summary}

Until recently hookworm disease has been a rarity in Great Britain. With the recent flood of immigrants from tropical countries in the Commonwealth this disease should be suspected as a possible cause in cases with iron-deficiency anaemia, gastrointestinal symptoms, or the malabsorption syndrome.

Four cases recently seen among Pakistanis resident in Oxford are described. The first presented with haematemesis and melaena followed by severe anaemia. A small-intestinal biopsy with a Crosby capsule brought up a live hookworm (Ancylostoma duodenale) and the jejunal mucosal specimen showed villous abnormalities and erosions. The load of hookworms was estimated to be about 800 worms as judged by the total eggcount of the faeces. The second case was typical of chronic iron-deficiency anaemia which had failed to respond to oral iron therapy but showed a rapid response as soon as a specific anthelmintic was used. This case also showed mucosal abnormalities in a jejunal biopsy specimen.

The two remaining cases were typical examples of irondeficiency anaemia. One of them had definite steatorrhoea and 
an abnormal jejunal biopsy specimen. Both responded well to treatment.

The stools of five contacts of the second patient and of four other Pakistanis have been examined and hookworm infestation has been found in five of them.

It is suggested that a public-health problem exists on two counts. First, there may be many immigrants suffering from hookworm infestation who need to be treated for the sake of their own health. Secondly, the possibility of the spread of hookworm disease in Great Britain must exist while such cases go untreated.

\section{REFERENCES}

Adams, A. R. D., and Maegraith, B. G. (1960). Clinical Tropical Diseases, 2nd ed. Blackwell, Oxford.

Blacklock, D. B., and Southwell, T. (1961). A Guide to Human Parasitology, 7th ed. Lewis, London.

Foy, H., and Kondi, A. (1960). Trans. roy. Soc. trop. Med. Hyg., 54, 419.

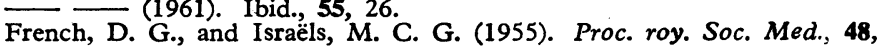
347.

Miller, G A. H and Bamforth J. (1962). Brit, med 7. 1, 1661.

Sheehy, T. W., Meroney, W. H., Cox, R. S., and Soler, J. E. (1962). Gastroenterology, 42, 148.

World Health Organization (1959). Tech. Rep. Ser., No. 182, p. 1.

\title{
Prevention of Poliomyelitis in Singapore by Live Vaccine
}

\author{
L. H. LEE,* M.B., B.S. ; K. A. LIM,* M.B., CH.B., B.SC. ; C. Y. TYE,* B.A.
}

Brit. med. F., 1964, 1, 1077-1080

In recent years Singapore's population has grown rapidly, accompanied by great improvement in general health standards. These changes are reflected in the data in Table $I$. Three-quarters of the population are Chinese, about $14 \%$ Malay, $8 \%$ Indian and Pakistani, and the remaining $3 \%$ are roughly equally divided between three groups-Eurasians, Europeans, and others.

TABLE I.-Trends in Some Vital Indices for Singapore, 1940-62

\begin{tabular}{c|c|c|c}
\hline & Population & $\begin{array}{c}\text { Crude Death Rate } \\
\text { per 1,000 Population }\end{array}$ & $\begin{array}{c}\text { Infant Mortality Rate } \\
\text { per 1,000 Live Births }\end{array}$ \\
\hline 1940 & 751,000 & $20 \cdot 9$ & $142 \cdot 6$ \\
1950 & $1,02,000$ & $12 \cdot 0$ & $82 \cdot 2$ \\
1960 & $1,64,000$ & $6 \cdot 2$ & $34 \cdot 9$ \\
1962 & $1,733,000$ & $5 \cdot 9$ & $31 \cdot 2$ \\
\hline
\end{tabular}

In recent years, too, the epidemiological pattern of poliomyelitis in Singapore has tended to show some transition from the endemic behaviour characteristic of countries with low health standards towards the epidemic behaviour characteristic of countries with high sanitary standards. However, cases continue to be confined predominantly to very young children, and the pattern is that of an endemic disease periodically breaking out in epidemic form. Such epidemic waves were seen in 1946 and 1948, soon after the war, but they subsequently appeared to be decreasing in violence until 1958, when an outbreak of over 400 cases occurred (see Table II).

TABLE II.-Notifications of Poliomyelitis in Singapore*

\begin{tabular}{c|c|c|c|c|c|c|c}
\hline Year & Cases & Year & Cases & Year & Cases & Year & Cases \\
\hline 1946 & 188 & 1951 & 94 & 1955 & 25 & 1959 & 62 \\
1947 & 0 & 1952 & 56 & 1956 & 72 & 1960 & 196 \\
1948 & 172 & 1953 & 47 & 1957 & 64 & 1961 & 53 \\
1949 & 78 & 1954 & 85 & 1958 & 415 & 1962 & 14 \\
1950 & 90 & & & & & & \\
\hline
\end{tabular}

* Non-paralytic cases rarely get to be notified, and the notification data therefore refer essentially to paralytic cases only.

During this epidemic, which was almost exclusively due to type 1 virus, an attempt was made to modify its course by wide-scale administration of type 2 attenuated virus (Sabin). This has been reported by Hale et al. (1959).

In 1959 the Singapore Government appointed a committee $^{1}$ to study the problems relating to the prevention of poliomyelitis in Singapore. In 1960 this committee carried out a serological and faecal survey and reported its findings to the Ministry of Health, Singapore (1961). In 1962 a mass immunization campaign was inaugurated, during which about $60 \%$ of children from 1 to 5 years of age received two doses of trivalent attenuated virus vaccine. In 1963 a routine programme was inaugurated whereby attenuated vaccine was given to young infants and to children first entering school.

This paper reports the investigations undertaken in the course of the committee's deliberations and the results to date of poliomyelitis immunization in Singapore.

\section{Survey}

This survey was designed to assess the immune status of children in Singapore and to study the results of the administration of type 2 vaccine in 1958-9.

Blood and stool specimens were taken from children below 5 years of age, this being the age-group principally effected by poliomyelitis in Singapore. The sample was drawn from healthy children attending at maternal and child health centres in both urban and rural areas. For the sake of homogeneity the survey was restricted to Chinese children. About $75 \%$ of the population at all ages are Chinese; therefore if other ethnic groups had been included their numbers would have been insufficient for comparative purposes unless the total sample size were greatly increased.

In the selection of subjects, those who had received Salk vaccine were excluded. Those who had documentary evidence or gave the date and time of receiving Sabin vaccine (type 2) during the previous campaign were classified as "vaccinated." Those who claimed never to have been vaccinated against poliomyelitis were classified as " nonvaccinated." In the latter group it was also ascertained that no other members of their household had been vaccinated. Response to the survey was voluntary and co-operation of the people was excellent.

By the time administrative difficulties had been overcome and the nature of the project explained to prospective sub-

* From the W.H.O. Regional Enterovirus Laboratory (formerly W.H.O. poliomyelitis centre in Singapore), Department of Bacteriology, University of Singapore and Department of Social Medicine and Public vealth, University of Singapore.

1 Government Committee on Poliomyelitis: Dr. Ng See Yook (chairman), Dr. K. Kanagaratnam, Dr. A. L. Gwee, Mr. C. Y. Tye, and Dr. L. H. Lee. Professor K. A. Lim was invited to advise the Committee. 